\title{
Molecular and Cytogenetic Studies on Abiotic Stress tolerance in wheat
}

\author{
Mohamed H. Harby ${ }^{1}$
}

\begin{abstract}
In the present experiment, ten Egyptian wheat (Triticum aestivum L.) cultivars were used, i.e. Gemmiza 9, Gemmiza 10, Gemmiza 11, Sids 1, Sids 2, Misr 1, Sakha 93, Giza 168, Shakha 94 and Shakha 95. Morphological, chemical, biochemical, and molecular markers were used to detect the genetic differentiation among the cultivars under different salt levels on seedling performance. The results indicated that there are highly significant variations between the studied wheat cultivars. For RAPD-PCR analysis, a total of 75 bands were detected among the studied cultivars., 53 bands showed polymorphism and for SSR markers a total of 11 bands were detected among the studied genotypes and 8 bands showed polymorphism
\end{abstract}

Key words: genetic differentiation, wheat, polymorphism, SSR.

\section{INTRODUCTION}

Wheat (Triticum aestivum L.) is one of the world's major cereal crops as the unique molecular makeup of its grain allows its use as a primary structural ingredient of breads, pastas, tortillas, and other products worldwide (Collard et al., 2005). Wheat (Triticum spp.) is a monocot and belongs to tribe Triticeae of family Poaceae (Gramineae). Other important crops like rice (Oryza sativa L.), maize (Zea mays L.) and bamboo also belong to this family (Shitsukawa et al., 2006).

Wheat is the main cereal grain crop grown in Egypt for thousands of years, serving as the principal source of calories in Egyptian diet. The productivity of Egyptian wheat cultivars has increased dramatically from $2.4 \mathrm{Mg}$ $\mathrm{ha}^{-1}$ in 1958 to $6.8 \mathrm{Mg} \mathrm{ha}^{-1}$ in 2004. Enrichment of genetic diversity plays a crucial role in wheat cultivar improvement (Chao et al., 2007). Genetic markers represent genetic differences between individual organisms or species.

Generally, they do not represent the target genes themselves but act as 'signs' or 'flags'. Genetic markers that are located in close proximity to genes (i.e. tightly linked) may be referred to as gene 'tags'. Such markers themselves do not affect the phenotype of the trait that interest because they are located only near or 'linked' to genes controlling the trait. All genetic markers occupy specific genomic positions within chromosomes (like genes) called 'loci' (singular 'locus'). There are three major types of genetic markers: (1) morphological (also 'classical' or 'visible') markers which themselves are phenotypic traits or characters; (2) biochemical markers, which include allelic variants of enzymes called isozymes; and (3) DNA (or molecular) markers, which reveal sites of variation in DNA (Jones et al., 1997)

\section{MATERIALS AND METHODS}

The present research was carried out at the Faculty of Agriculture, Alexandria University, Egypt during the seasons of 2019 up to 2020 to study the morphological, biochemical, and molecular genetic markers of some selected bread wheat cultivars to detect the genetic differentiation. Ten seeds were sown in each pot from each cultivar in Selica-jel after washing with adequate amount of distill water. Sodium chloride solution was applied after 8 days of germination in four levels $(0 \mathrm{mM}, 50 \mathrm{mM}$, $150 \mathrm{mM}$ and $200 \mathrm{mM}$ ) were applied as foliar spray after three weeks of germination. The following morphological parameters were measured: shoot length $(\mathrm{cm})$, root length $(\mathrm{cm})$, No of leaves/plant, No of roots/plant and proline content. Completely Randomized Design (CRD) with four replicates was used.

Leaves from each cultivar were grounded separately, using a cooled mortar with a pestle, and adding $0.23 \mathrm{M}$ Tris-acetate, $\mathrm{pH}$ 5.0. Homogenate was extracted by the solution containing Tris $(27.7 \mathrm{~g})$ and citric acid (11.0 g) in one liter volume adjusted with distilled water. Electrophoresis was carried out by the prescriptions recommending $1 \%$ agar-starch-polyvinyl-pyrrolidone gel and Tris-orate or Tris- acetate separation buffers. Electrophoresis was conducted at $270 \mathrm{v}, 4^{\circ} \mathrm{C}$ for $100 \mathrm{~min}$. $100 \mathrm{ml}$ of $0.01 \mathrm{M}$ acetate buffer $\mathrm{pH} 5.0$, containing $0.1 \%$ benzidine and $0.5 \%$ hydrogen peroxide $\left(\mathrm{H}_{2} \mathrm{O}_{2}\right)$ were layered over the gel immediately before staining (Sabrah, 1980). Proline was determined according to the method of Bates et al., (1973) by 3\% aqueous sulfosalicylic acid, acid ninhydrin: $1.25 \mathrm{gm}$ ninhydrin, $30 \mathrm{ml}$ glacial acetic acid, $20 \mathrm{ml} 6 \mathrm{M}$ phosphoric acid.

RAPD analysis was carried out using 10 oligonucleotide primers (Table 1) that were selected from the Operon Kit (Operon Technologies Inc., Alabameda, $\mathrm{CA})$. The polymerase chain reaction mixture $(25 \mu \mathrm{l})$ consisted of $13 \mu \mathrm{l}$ master mix (Promega) Taq DNA polymerase; $2 \mu \mathrm{l}$ of genomic DNA, $2 \mu 1$ primer, $8 \mu 1$ deionized weter. PCR amplification was performed in a BiometraT1 gradient thermal cycler for 35 cycles after initial denaturation for $5 \mathrm{~min}$ at $94^{\circ} \mathrm{C}$. Each cycle consisted of denaturation at $94^{\circ} \mathrm{C}$ for $1 \mathrm{~min}$; annealing at $36^{\circ} \mathrm{C}$ for $1 \mathrm{~min}$; extension at $72^{\circ} \mathrm{C}$ for $2 \mathrm{~min}$ and final

DOI: 10.21608/ASEJAIQJSAE.2020.129275

${ }^{1}$ Faculty of Agriculture, Alexandria, University, Alexandria, Egypt

Received November 2, 2020, Accepted, December 12, 2020. 
extension at $72^{\circ} \mathrm{C}$ for $5 \mathrm{~min}$ (Williames et al., 1980). Amplification products were separated on $2 \%$ agarose gels at 100 volts for $1.30 \mathrm{hrs}$ with $1 \mathrm{x}$ TBE buffer. To detect ethidium bromide/DNA complex, agarose gels were examined on ultraviolet transilluminator $(302 \mathrm{~nm}$ wave length) and photographed. Using 100pb Plus DNA ladder, ready-to-use (Gene Ruler, Fermentas, and Life Sciences), the length of the different DNA fragments were determined. For each sample, the reproducible DNA bands from two runs were scored for their presence or absence.

Table 1. Primers name and their oligonucleotide sequences used in the current study.

\begin{tabular}{|c|c|}
\hline Primer Code & Sequence \\
\hline OPN-04 & $5-$ GACCGACCCA -3 \\
\hline OPD-05 & $5{ }^{`}-\mathrm{TGAGCGGACA}-3^{\prime}$ \\
\hline OPC-05 & $5^{`}-\mathrm{GATGACCGCC}-3^{`}$ \\
\hline OPM-05 & 5`-GGGAACGTGT -3` \\
\hline OPB-07 & 5-GAAACGGGTG -3` \\
\hline OPN-10 & $5^{`}$-ACAACTGGGG -3 \\
\hline OPG-12 & $5-C A G C T C A C G A-3 `$ \\
\hline OPQ-12 & 5 - AGTAGGGCAC -3 \\
\hline OPN-13 & 5-AGCGTCACTC - 3` \\
\hline OPQ-14 & 5-GGACGCTTCA -3 \\
\hline
\end{tabular}

Simple Sequence Repeats (SSRs), also known as microsatellites, are repeating sequences of nucleotides, such as (AC)n. They have been found in abundance on most eukaryotic chromosomes and are often highly polymorphic (Rafalski and Tingey 1993). Five SSR markers described (Kong et al., 2000) were used for genotyping assays (Table 2). One way ANOVA in completely randomized experiments was used to reveal the significant differences among the samples. The LSD test was conducted to identify the significant differences among the means at 5\% level of probability (Siugh, 1994).

Table 2. Sequences of the SSR loci and annealing temperature for $\mathrm{PCR}$ reaction used in the current study

\begin{tabular}{|c|c|}
\hline Locus & $\begin{array}{l}\text { Sequence of forward and reveres } \\
\text { primers }\end{array}$ \\
\hline \multirow[t]{2}{*}{ Wmc661 } & F: CCACCATGGTGCTAATAGTGTC \\
\hline & R: AGCTCGTAACGTAATGCAACTG \\
\hline \multirow[t]{2}{*}{ Xtxp-8 } & F: ACAT CTACT AC CCT CTCACC \\
\hline & R: ACACATCGAGACCAGTTG \\
\hline \multirow[t]{2}{*}{ Xtxp-10 } & F: ATACTATCAAGAGGGGAGC \\
\hline & R; AGTACTAGCCACACGTCAC \\
\hline \multirow[t]{2}{*}{ Xtxp-12 } & F: ATAT GGAAGGAAGAAGC C GG \\
\hline & R: AACACAACAT GCAC GCAT G \\
\hline \multirow[t]{2}{*}{ Xtxp-19 } & F: ATACTATCAAGAGGGGAGC \\
\hline & R: AGTACTAGCCACACGTCAC \\
\hline
\end{tabular}

\section{RESULTS AND DISCUSSION}

\section{Morphological markers}

Regarding on the morphological markers, results presented in Table 3 indicated significant variations among the Egyptian wheat cultivars in the seedling and root length $(\mathrm{cm})$. sids 2 was the highest one by average $18.95 \mathrm{~cm}$, followed by misr 1 in average $18.68 \mathrm{~cm}$, while Gemmeiza 10 was the shortest one $(15.04 \mathrm{~cm})$. Concerning to the Egyptian wheat cultivars data indicated significant values between Sakha 93, Giza 168 and the other cultivars. Sooht length of Giza 168 was $(15.67 \mathrm{~cm})$ followed by Sakha $93(13.90 \mathrm{~cm})$., however no significant variations were observed between Gemmeiza 9, Sakha 94 and Sakha 95. The range between Egyptian wheat cultivars in relation to shoot length ranged from $18.95 \mathrm{~cm}$ (Sids 2) to $13.28 \mathrm{~cm}$ (Gemmeiza 9) by value $~ 5.67$ increasing $35 \%$ and between the shortest cultivars ranged from 15.05 (GEMMIZA11) to 13.28 (Gemmeiza 9) in increase by $\sim 10 \%$ (Table 3).

According to root length, results indicated significant variations among all studied wheat cultivars. The Sakha 93 wheat cultivar recorded the highest value $(4.29 \mathrm{~cm})$ followed by Gemmeiza 10 in average $4.09 \mathrm{~cm}$, while Gemmeiza 11 and Sakha 94 was the shortest in average 2.56 and $2.56 \mathrm{~cm}$, in respect. The highest root length was recorded to Sakha 93 in average $4.29 \mathrm{~cm}$ followed by Gemmeiza $11(4.09 \mathrm{~cm})$. The range between Egyptian wheat cultivars in root length ranged from $4.29 \mathrm{~cm}$ (Sakha 93) to $2.56 \mathrm{~cm}$ (Sids 1) by value $=1.73 \sim$ increasing $40 \%$ (Table 3). Wheat cultivars showed decrease in root length with increasing the salt levels until $200 \mathrm{mM}$ salt, Sakha 93 and followed by Gemmeiza 11 showed the tallest root length $(4.33$ and $3.83 \mathrm{~cm})$, respectively. While Sakha 95 showed the shortest root $(2.33 \mathrm{~cm}$.) under $200 \mathrm{mM}$ of sodium chloride.

Results in Table 4 indicated no significant variations were observed among all the studied wheat cultivars in number of leaves/seedling except with Sids 2 . The Sids 2 wheat cultivar recorded the highest value (2.44). Analysis of variance in Table 4 showed significant variation between the wheat in relation to number of leaves/seedling by L.S.D. $0.05=0.218$, and no significant variation was observed among Sids 1 and Sids 2 . Concerning to the wheat cultivars data indicated no significant values between all the cultivars.

Results in Table 4 indicated significant variations among all the studied wheat cultivars in number of roots/seedling. Gemmeiza 10 wheat cultivar recorded the highest value (7.01). Analysis of variance in Table 4 showed significant variation between the wheat in relation to number of roots/seedling by L.S.D. $0.05=0.199$, and data indicated that no significant variation was observed among Gemmeiza 10and Gemmeiza 11. 
Table 3. Seedling and root length (cm) of Egyptian wheat cultivars as affected by four different salinity concentrations and their interaction during 2019 - 2020 seasons.

\begin{tabular}{|c|c|c|c|c|c|c|c|c|c|c|}
\hline \multicolumn{5}{|c|}{ shoot length $(\mathrm{cm})$} & \multicolumn{6}{|c|}{ Root length $(\mathrm{cm})$} \\
\hline \multirow{2}{*}{$\begin{array}{l}\text { Treatment } \\
\text { Variety }\end{array}$} & \multicolumn{4}{|c|}{ Salinity concentration } & \multirow[t]{2}{*}{ Mean } & \multicolumn{4}{|c|}{ Salinity concentration } & \multirow[t]{2}{*}{ Mean } \\
\hline & $\mathbf{0}$ & 50 & 150 & 200 & & $\mathbf{0}$ & 50 & 150 & 200 & \\
\hline Gemmiza 11 & 17.67 & 16.54 & 15.09 & 15.10 & $16.10^{\mathrm{b}}$ & 5.40 & 4.07 & 3.07 & 3.83 & $4.09^{b}$ \\
\hline Gemmiza 10 & 18.19 & 13.23 & 14.27 & 14.46 & $15.04^{\mathrm{d}}$ & 6.18 & 2.93 & 3.23 & 3.23 & $3.89^{c}$ \\
\hline Sids 1 & 16.13 & 16.28 & 15.37 & 15.11 & $15.72^{\mathrm{c}}$ & 2.63 & 2.63 & 2.37 & 2.62 & $2.56^{\mathrm{f}}$ \\
\hline Sids 2 & 18.37 & 20.57 & 17.20 & 19.67 & $18.95^{\mathrm{a}}$ & 3.17 & 2.55 & 2.55 & 2.67 & $2.74^{\mathrm{f}}$ \\
\hline misr 1 & 17.97 & 19.77 & 18.46 & 18.53 & $18.68^{\mathrm{a}}$ & 4.47 & 4.37 & 2.90 & 3.40 & $3.79^{c}$ \\
\hline Sakha 93 & 14.27 & 14.82 & 12.80 & 13.72 & $13.90^{\mathrm{f}}$ & 4.53 & 4.50 & 3.80 & 4.33 & $4.29^{\mathrm{a}}$ \\
\hline Geiza 168 & 14.42 & 14.24 & 14.37 & 15.67 & $14.68^{\mathrm{e}}$ & 4.57 & 2.93 & 3.07 & 3.43 & $3.50^{\mathrm{d}}$ \\
\hline Gammeiza 9 & 12.87 & 12.13 & 14.40 & 13.73 & $13.28^{\mathrm{g}}$ & 3.87 & 1.87 & 3.33 & 2.80 & $2.97^{\mathrm{e}}$ \\
\hline Sakha 94 & 13.82 & 12.26 & 12.73 & 14.33 & $13.29^{\mathrm{g}}$ & 3.13 & 2.17 & 2.10 & 3.20 & $2.65^{\mathrm{f}}$ \\
\hline Sakha 95 & 13.97 & 13.63 & 12.66 & 13.50 & $13.44^{\mathrm{g}}$ & 3.86 & 3.20 & 2.87 & 2.33 & $3.07^{\mathrm{e}}$ \\
\hline Mean & $15.77^{\mathrm{a}}$ & $15.35^{\mathrm{b}}$ & $14.74^{\mathrm{c}}$ & $15.38^{\mathrm{b}}$ & & $4.18^{\mathrm{a}}$ & $3.09^{\mathrm{c}}$ & $2.93^{\mathrm{d}}$ & $3.21^{\mathrm{b}}$ & \\
\hline \multicolumn{3}{|c|}{ LSD at $0.05(\mathrm{~V})$} & \multicolumn{2}{|c|}{0.288} & \multicolumn{6}{|c|}{0.163} \\
\hline \multicolumn{3}{|c|}{ LSD at 0.05 (SC) } & \multicolumn{2}{|c|}{0.181} & \multicolumn{6}{|c|}{0.103} \\
\hline \multicolumn{3}{|c|}{ LSD at $0.05(\mathrm{~V} \mathrm{x} \mathrm{SC})$} & \multicolumn{2}{|c|}{0.573} & \multicolumn{6}{|c|}{0.326} \\
\hline
\end{tabular}

Table 4. Number of leaves and roots/seedling of Egyptian wheat cultivars asaffected by four different salinity concentrations and their interaction during 2019 - 2020 seasons.

\begin{tabular}{|c|c|c|c|c|c|c|c|c|c|c|}
\hline \multicolumn{5}{|c|}{ Number of leaves/seedling } & \multicolumn{5}{|c|}{ Number of roots/seedling } & \multirow{3}{*}{ Mean } \\
\hline \multirow{2}{*}{\begin{tabular}{|l|} 
Treatment \\
Variety
\end{tabular}} & \multicolumn{4}{|c|}{ Salinity concentration } & \multirow[t]{2}{*}{ Mean } & \multicolumn{4}{|c|}{ Salinity concentration } & \\
\hline & $\mathbf{0}$ & 50 & 150 & 200 & & $\mathbf{0}$ & 50 & 150 & 200 & \\
\hline Gemmiza 11 & 2.67 & 2.00 & 2.07 & 2.00 & $2.19^{\mathrm{b}}$ & 7.60 & 7.00 & 6.87 & 5.90 & $6.84^{\mathrm{a}}$ \\
\hline Gemmiza 10 & 2.53 & 2.00 & 2.07 & 2.00 & $2.15^{\mathrm{b}}$ & 7.47 & 7.13 & 6.96 & 6.47 & $7.01^{\mathrm{a}}$ \\
\hline Sids 1 & 2.47 & 2.60 & 2.10 & 2.10 & $2.32^{\mathrm{ab}}$ & 6.70 & 6.27 & 6.53 & 6.13 & $6.41^{\mathrm{b}}$ \\
\hline Sids 2 & 2.67 & 2.10 & 2.00 & 3.00 & $2.44^{\mathrm{a}}$ & 6.10 & 6.13 & 4.40 & 5.80 & $5.61^{\mathrm{d}}$ \\
\hline misr 1 & 2.67 & 2.00 & 2.00 & 2.00 & $2.17^{\mathrm{b}}$ & 6.80 & 7.50 & 6.00 & 5.33 & $6.41^{\mathrm{b}}$ \\
\hline Sakha 93 & 2.67 & 2.00 & 2.00 & 2.00 & $2.17^{\mathrm{b}}$ & 6.13 & 6.93 & 6.47 & 6.50 & $6.51^{\mathrm{b}}$ \\
\hline Geiza 168 & 2.67 & 2.00 & 2.00 & 2.00 & $2.17^{\mathrm{b}}$ & 6.67 & 6.33 & 6.87 & 6.50 & $6.59^{b}$ \\
\hline Gammeiza 9 & 2.67 & 1.80 & 2.00 & 2.00 & $2.12^{\mathrm{b}}$ & 5.87 & 5.10 & 5.27 & 5.47 & $5.43^{\mathrm{d}}$ \\
\hline Sakha 94 & 2.67 & 2.00 & 2.00 & 2.00 & $2.17^{\mathrm{b}}$ & 6.60 & 5.40 & 6.33 & 6.00 & $6.08^{\mathrm{c}}$ \\
\hline Sakha 95 & 2.67 & 2.00 & 2.00 & 2.00 & $2.17^{\mathrm{b}}$ & 6.60 & 6.10 & 6.13 & 5.40 & $6.06^{\mathrm{c}}$ \\
\hline Mean & $2.64 \mathrm{a}$ & $2.05 \mathrm{~b}$ & $2.02^{\mathrm{b}}$ & $2.11 \mathrm{~b}$ & & $6.65^{\mathrm{a}}$ & $6.39 \mathrm{~b}$ & $6.18 \mathrm{c}$ & $5.95 \mathrm{~d}$ & \\
\hline LSD at $0.05(\mathrm{~V})$ & & & 0.2 & & & & 0.1 & & & \\
\hline LSD at $0.05(\mathrm{SC})$ & & & 0.1 & & & & 0.1 & & & \\
\hline LSD at $0.05(\mathrm{~V} \times \mathrm{SC})$ & & & 0.4 & & & & 0.3 & & & \\
\hline
\end{tabular}

Concerning to the wheat cultivars data in Table 4 indicated no significant difference between Sakha 93 and Giza 168, also between Sakha 94 and Sakha 95 cultivars.

Our data are agreed with those reported by (Hamada, 1996) which assessed 13 Aegilops and three wild Triticum originally Turkish species by using morphological, pathological, qualitative and agricultural traits. Also, our result is agreed with Hamada, (1996) used 12 yield parameters and 5 morphological traits of spring wheat to evaluate genetic divergence among 19 durum wheat genotypes. These genotypes were subsequently classified into 7 separate clusters revealing high level of genetic divergence independent of original culdivated zone. The present work is agreement with $\mathrm{Hu}$ and Schmidhalter (1998). who reported that wheat growing in $120 \mathrm{mM}$ $\mathrm{NaCl}$ reacted with a $25 \%$ reduction in growth rate, $\mathrm{Na}^{+}$in the growing cells of leaves was at maximum only $20 \mathrm{mM}$, and $\mathrm{Cl}^{-}$only $60 \mathrm{mM}$. However, Ball (1998) found that the common decrease in leaf expansion is not related to a loss 
in turgor pressure and is most likely a result of a change in hormonal signaling from roots to leaves In the saltsensitive genotypes, in which salt is not effectively excluded from the transpiration stream, salt will build up to toxic levels in the leaves, resulting in death of old leaves and new leaves becoming injured and succulent (Munns and James, 2003). Our results are agreement with Ashraf et al., (1986) who reported that root length can be used as selection criteriou under salinity stress.

Heritability estimates were low under 200 and $250 \mathrm{mM}$ $\mathrm{NaCl}$ stress indicating that improvement in root length is difficult under stress conditions. Our results are agreement with Hasegawa et al., (2000) who reported that roots play several important roles during plant growth and development and are typically the first part of the plant to encounter salinity. In glycophytes, the root is the primary site of salt stress and the ability to maintain ion homeostasis and redox potential is critical for the normal root growth and function under saline stress.

\section{Chemical markers}

Results in Table 5 indicated significant variations among all the studied wheat cultivars in chlorophyll. The misr1 wheat cultivar recorded the highest value (30.55) followed by GIZA 168, GEMMIZA 9 and GEMMIZA 11 by average 29.93 ,

29.24 and 29.04, respectively. Analysis of variance in Table 5 showed significant variation between the wheat cultivars in relation to Chlorophyll by L.S.D. $.0 .05=0.825$. The reduction in chlorophyll content under salinity agreed with those reported by Iqbal et al., (2006)

Decrease in total chlorophyll content could be due to ion accumulation and functional disorders observed during stomata opening and closing under salinity stress (Nawaz et al., 2010). Another reason for the decrease of chlorophyll content under salt conditions is stated to be the rapid maturing of leaves (Nawaz et al., 2010). Decrease in chlorophyll content under salinity stress is observed more in salt sensitive genotypes in comparison to cultivars with low tolerance (Khan et al., 2009).

Proline content was determined as indicator for salt tolerant in the studied wheat genotypes. Results showed that the proline content was increased by increasing concentration of salt. The regression coefficient was done to determine the relationship between the two variables. Proline was considered as the dependent factor $(\mathrm{Y})$ while the salt concentration was determined as the independent variable (X) for the cultivars. Analysis of variance in Table 5 and fig. 1 showed significant variation between wheat cultivars in proline content under different salt concentrations. The highest values with no significant were recorded to misr 1 and Gemmeiza 11 in average 1.05 and 1.04 in respect with L.S.D. $=0.034$, while the lowest value was recorded to Sakha 93 with average 0.55 .

Table 5. Chlorophyll (SPAD unit) and Proline content ( $\mu$ moles/g/fresh weight) of Egyptian wheat varieties as affected by four different salinity concentrations and their interaction during $2019-2020$ seasons.

\begin{tabular}{|c|c|c|c|c|c|c|c|c|c|c|}
\hline \multirow{3}{*}{$\begin{array}{l}\text { Treatment } \\
\text { Variety } \\
\end{array}$} & \multicolumn{4}{|c|}{ Chlorophyll (SPAD unit) } & \multicolumn{6}{|c|}{ Proline ( $\mu$ moles/g/fresh weight) } \\
\hline & \multicolumn{4}{|c|}{ Salinity concentration } & \multirow[t]{2}{*}{ Mean } & \multicolumn{3}{|c|}{ Salinity concentration } & \multirow[b]{2}{*}{200} & \multirow[t]{2}{*}{ Mean } \\
\hline & $\mathbf{0}$ & 50 & 150 & 200 & & $\mathbf{0}$ & 50 & 150 & & \\
\hline Gemmiza 11 & 27.73 & 28.07 & 26.07 & 27.13 & & 0.453 & 1.18 & 1.12 & 1.38 & \\
\hline Gemmiza 10 & 25.33 & 29.40 & 31.20 & 30.33 & $29.07 \mathrm{c}$ & 0.488 & 0.533 & 0.670 & 0.995 & $0.67 \mathrm{e}$ \\
\hline Sids 1 & 26.93 & 25.73 & 27.73 & 22.07 & $25.62 \mathrm{f}$ & 0.727 & 0.798 & 0.320 & 0.592 & $0.61 \mathrm{f}$ \\
\hline Sids 2 & 31.67 & 27.30 & 25.27 & 21.87 & $26.53 \mathrm{e}$ & 0.436 & 0.833 & 0.769 & 1.27 & $0.83 \mathrm{~b}$ \\
\hline misr 1 & 27.73 & 29.13 & 34.27 & 31.07 & $30.55 \mathrm{a}$ & 0.727 & 1.09 & 1.19 & 1.20 & $1.05 \mathrm{a}$ \\
\hline Sakha 93 & 21.67 & 28.00 & 24.40 & 28.13 & $25.55 \mathrm{f}$ & 0.530 & 0.631 & 0.593 & 0.426 & $0.55 \mathrm{~g}$ \\
\hline Geiza 168 & 33.00 & 28.40 & 29.93 & 28.40 & $29.93^{\mathrm{ab}}$ & 0.644 & 0.468 & 0.543 & 1.24 & $0.72 \mathrm{~d}$ \\
\hline Gammeiza 9 & 34.73 & 26.93 & 33.70 & 21.60 & $29.24^{\mathrm{bc}}$ & 0.447 & 0.570 & 0.441 & 1.09 & $0.64 \mathrm{f}$ \\
\hline Sakha 94 & 26.87 & 23.93 & 25.10 & 24.40 & $25.08 \mathrm{f}$ & 0.488 & 0.589 & 1.08 & 1.17 & $0.83 \mathrm{~b}$ \\
\hline Sakha 95 & 25.93 & 21.60 & 29.30 & 32.93 & $27.44 \mathrm{~d}$ & 0.757 & 0.644 & 0.824 & 0.886 & $0.78 \mathrm{c}$ \\
\hline \multirow[t]{2}{*}{ Mean } & $28.16 \mathrm{~b}$ & $26.85 \mathrm{c}$ & $28.70 \mathrm{a}$ & $26.79 \mathrm{c}$ & & $0.57 \mathrm{c}$ & $0.73 b$ & $0.76 \mathrm{~b}$ & $1.02 \mathrm{a}$ & \\
\hline & $2.64^{\mathrm{a}}$ & $2.05^{\mathrm{b}}$ & $2.02^{\mathrm{b}}$ & $2.11^{\mathrm{b}}$ & & $6.65^{\mathrm{a}}$ & $6.39^{\mathrm{b}}$ & $6.18^{\mathrm{c}}$ & $5.95^{\mathrm{d}}$ & \\
\hline \multicolumn{3}{|c|}{ LSD at $0.05(\mathrm{~V})$} & \multicolumn{2}{|c|}{0.825} & \multicolumn{6}{|c|}{0.034} \\
\hline \multicolumn{3}{|c|}{ LSD at $0.05(\mathrm{SC})$} & \multicolumn{2}{|c|}{0.522} & \multicolumn{6}{|c|}{0.022} \\
\hline \multicolumn{3}{|c|}{ LSD at $0.05(\mathrm{~V} \times \mathrm{SC})$} & \multicolumn{2}{|c|}{1.65} & \multicolumn{6}{|c|}{0.068} \\
\hline
\end{tabular}




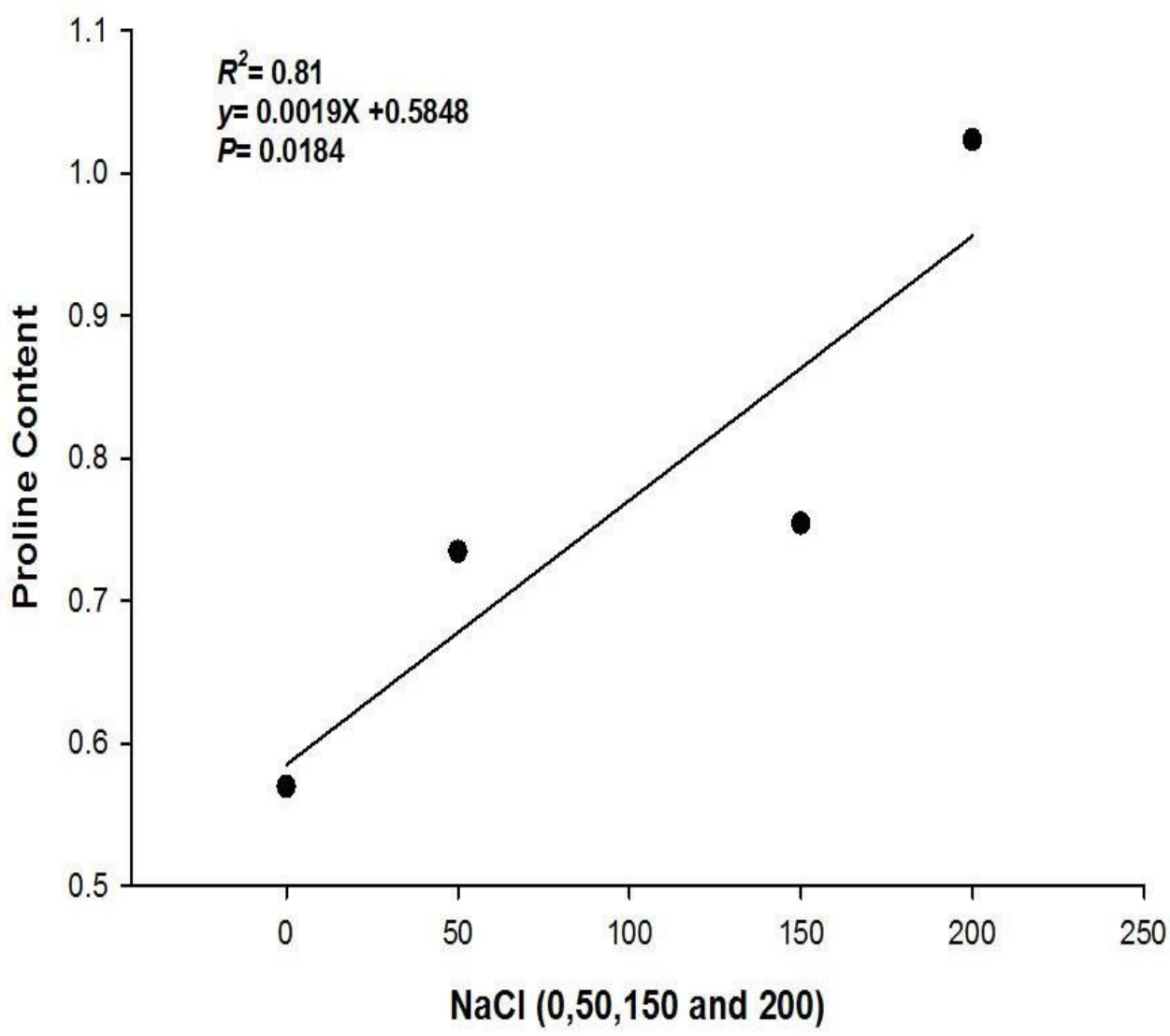

Fig. 1. Regression between salt concentrations ( $\mathrm{X}$-factor) and the proline ( $\mathrm{Y}$ - factor) in wheat cultivars

Proline is the only organic cytosolute which able to make the major contribution or osmotic adjustment at sever salinity in roots, while in shoots and spikes the contribution of proline in osmoregulation might be reduced. We concluded that there is no stable situation in usage of organic or inorganic soluble components in osmotic adjustment in the cultivars and lines on different salinity levels. This is happened not only in different cultivars, but also in different organs which conferring the contrasting opinions about the physiological significance of proline which has remained controversial among physiologists. Many reports have pointed out that proline is mostly accumulated when plants growth ceased (Joly et al., 2000).

The overall results of the present study indicated that for all wheat cultivars grown at $50 \mathrm{Mm}, 150 \mathrm{Mm}$, and $200 \mathrm{Mm}$ of salt maintained a higher proline level than those grown at control as Figure 30. The increment of proline level was higher under high salt concentration than that in low salt concentration. Increasing praline level due to high salt can be used to screen wheat genotypes, which is comparable to cell membrane thermo-stability test

\section{Biochemical markers}

Peroxidase isozymes exhibited a wide range of variability among the different cultivars at different localities. In control three loci were obtained for all cultivars as two cathodal Pex.1c and Pex. 2a found as common band and Pex 2c was unique for some wheat, while, Pex $3 \mathrm{c}$ was unique for some wheat cultivars. With increase of salt levels the results showed increase in number of loci (4 and 5) as shown with $200 \mathrm{Mm}$ salt two anodal (Pex.1A and Pex.2A) were found as common band for all the wheat samples. While (pex.1c) at cathodal was as common band for all the wheat samples. misr1 wheat cultivar gives two bands in cathodal (Pex.2c and Pex.4c). 
Our results in a line with Hassanein (1999) who reported that the results showed that band number was exhibited in untreated and treated plants with salt of all cultivars. This band was higher densities and intensities in the salt treated cultivars than grown under control conditions. These results indicated that salt stress increased the accumulation of the esterase enzyme and that encoding gene(s) which accelerated in response to salt stress. Salinity increase esterase isozymes, the highest number of esterase isozymes were detected under the highest $\mathrm{NaCl}$ concentration.

\section{Molecular markers}

A total of 75 bands were detected among the studied cultivars. 53 bands showed polymorphism. Out of these polymorphic bands, 13 unique bands were scored and the number of monomorphic bands was 9 (Table 6). Results indicated clearly that OPC-05 and OPQ-14 showed three unique fragments followed by OPM- 05 and OPG-12 by two unique fragments. However, the primer OPC-05, OPM- 05 OPN-10 and OPG-12 show $100 \%$ polymorphism. While primer OPN-04, OPD-05, OPB07, OPQ-12, OPN-13 and OPQ-14 showed 60, 88,
$80,75,60$ and $89 \%$ polymorphism, respectively. The range of DNA size was between $138 \mathrm{bp}$ and $1825 \mathrm{bp}$. Molecular markers have also been extensively used to analyze the genetic diversity in crop plants. Based on the data obtained by RAPD analysis, it was possible to discriminate between the ten wheat cultivars used. The genotype-specific markers indicated that the highest number of RAPD specific markers was scored for OPC05 and OPQ-14 (3 markers), while both OPM-05, and OPG-12 scored two markers each. On the other hand, OPD-05, OPQ-12 and OPN-13 scored one marker each as Table 6 and Figure 2.

For SSR markers a total of 11 bands were detected among the studied genotypes. 8 bands showed polymorphism. Out of these polymorphic bands, 3 bands were monomorphic. However, the primer wmc661and primer xtxp19 shows $100 \%$ polymorphism. While primer XTXP8, and XTXP12 showed 50\% polymorphism, respectively. The range of DNA size was between 84bp in primer wmc 661 to $254 \mathrm{bp}$ in primer XTXP12 as Table 7 and Figure 3.

Table 6. Polymorphism data as detected by RAPD markers, total number of amplicons, monomorphic and polymorphic amplicons and the percentage of polymorphism among the ten cultivars.

\begin{tabular}{lcccccc}
\hline $\begin{array}{l}\text { Primer } \\
\text { code }\end{array}$ & $\begin{array}{c}\text { Total } \\
\text { amplicons }\end{array}$ & $\begin{array}{c}\text { Mono- } \\
\text { morphic }\end{array}$ & polymorphic & unique & $\begin{array}{c}\text { Positive unique } \\
\text { markers }\end{array}$ & $\begin{array}{c}\text { Polym- } \\
\text { orphism \% }\end{array}$ \\
\hline OPN-04 & 5 & 2 & 3 & 0 & - & 60 \\
OPD-05 & 8 & 1 & 6 & 1 & 1096 & 88 \\
OPC-05 & 7 & 0 & 4 & 3 & $582-292-275$ & 100 \\
OPM-05 & 14 & 0 & 12 & 2 & $608-290$ & 100 \\
OPB-07 & 5 & 1 & 4 & 0 & - & 80 \\
OPN-10 & 6 & 0 & 6 & 0 & - & 100 \\
OPG-12 & 8 & 0 & 6 & 2 & $277-188$ & 100 \\
OPQ-12 & 8 & 2 & 5 & 1 & 199 & 75 \\
OPN-13 & 5 & 2 & 2 & 1 & 487 & 60 \\
OPQ-14 & 9 & 1 & 5 & 3 & $417-306-213$ & 89 \\
Total & 75 & 9 & 53 & 13 & 13 & 85.2 \\
Average polymorphism \% & & & & &
\end{tabular}

Table 7. Number of alleles, fragment size range and polymorphism detected by SSR loci in the ten wheat genotypes

\begin{tabular}{lccccc}
\hline Primer & $\begin{array}{c}\text { Fragment } \\
\text { size (bp) }\end{array}$ & $\begin{array}{c}\text { Number of } \\
\text { alleles }\end{array}$ & $\begin{array}{c}\text { Monomorphic } \\
\text { bands }\end{array}$ & $\begin{array}{c}\text { Polymorphic } \\
\text { bands }\end{array}$ & $\begin{array}{c}\text { Polymorphic } \\
\text { bands\% }\end{array}$ \\
\hline wmc661 & $84-101$ & 2 & 0 & 2 & 100 \\
xtxp8 & $140-244$ & 2 & 1 & 1 & 50 \\
xtxp10 & 272 & 1 & 1 & 0 & 0 \\
xtxp12 & $221-254$ & 2 & 1 & 1 & 50 \\
xtxp19 & $143-253$ & 3 & 0 & 3 & 100 \\
\hline
\end{tabular}



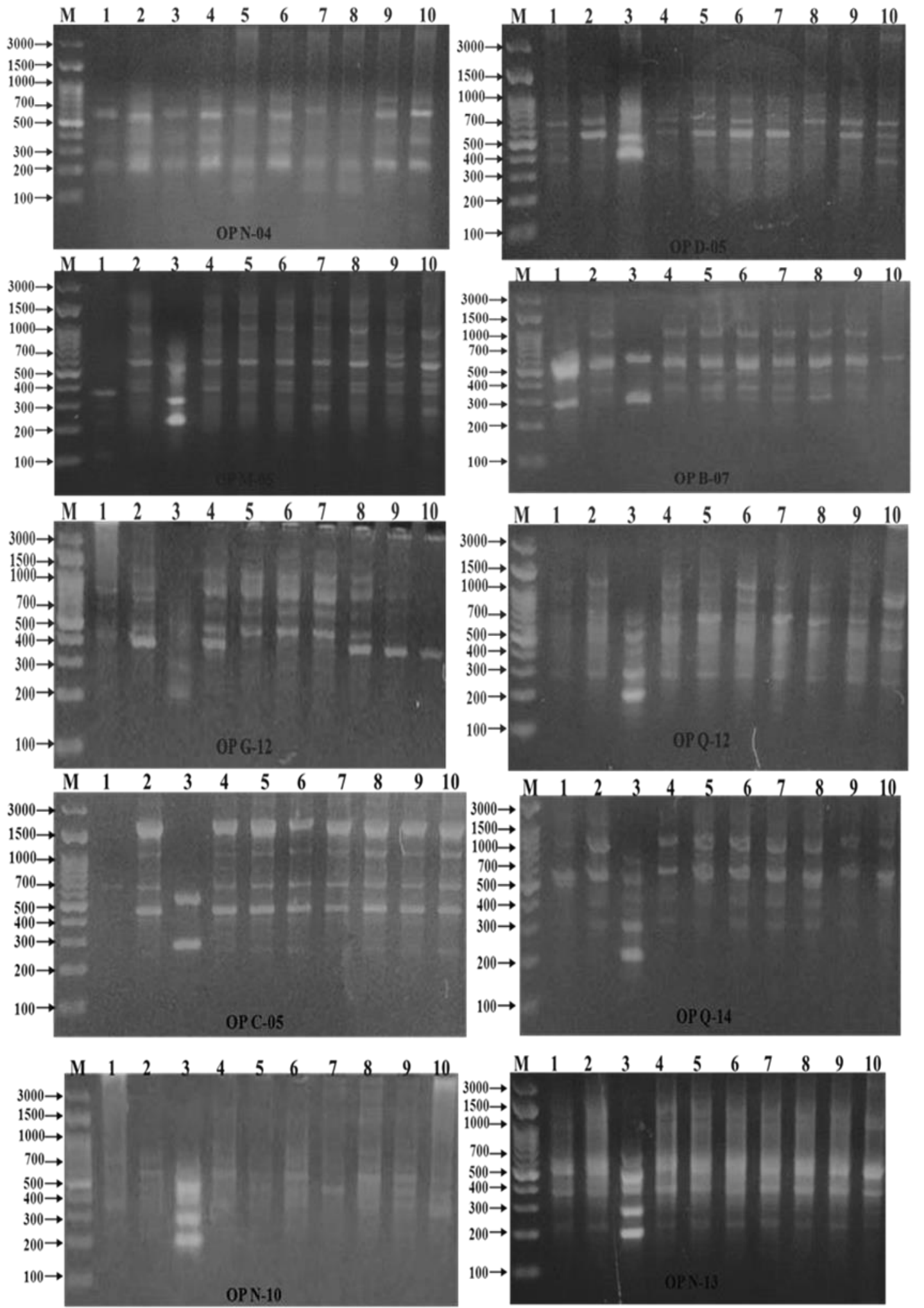

Fig. 2. DNA polymorphism of the Egyptian wheat cultivars using RAPD DNA (1) Sakha93, (2) Geiza168, (3) Gammeiza9, (4) Sakha94, (5) misr1, (6) Gammeiza10, (7) Gammeiza11, (8) Sids 1, (9) Sids 2, and (10) Sa 

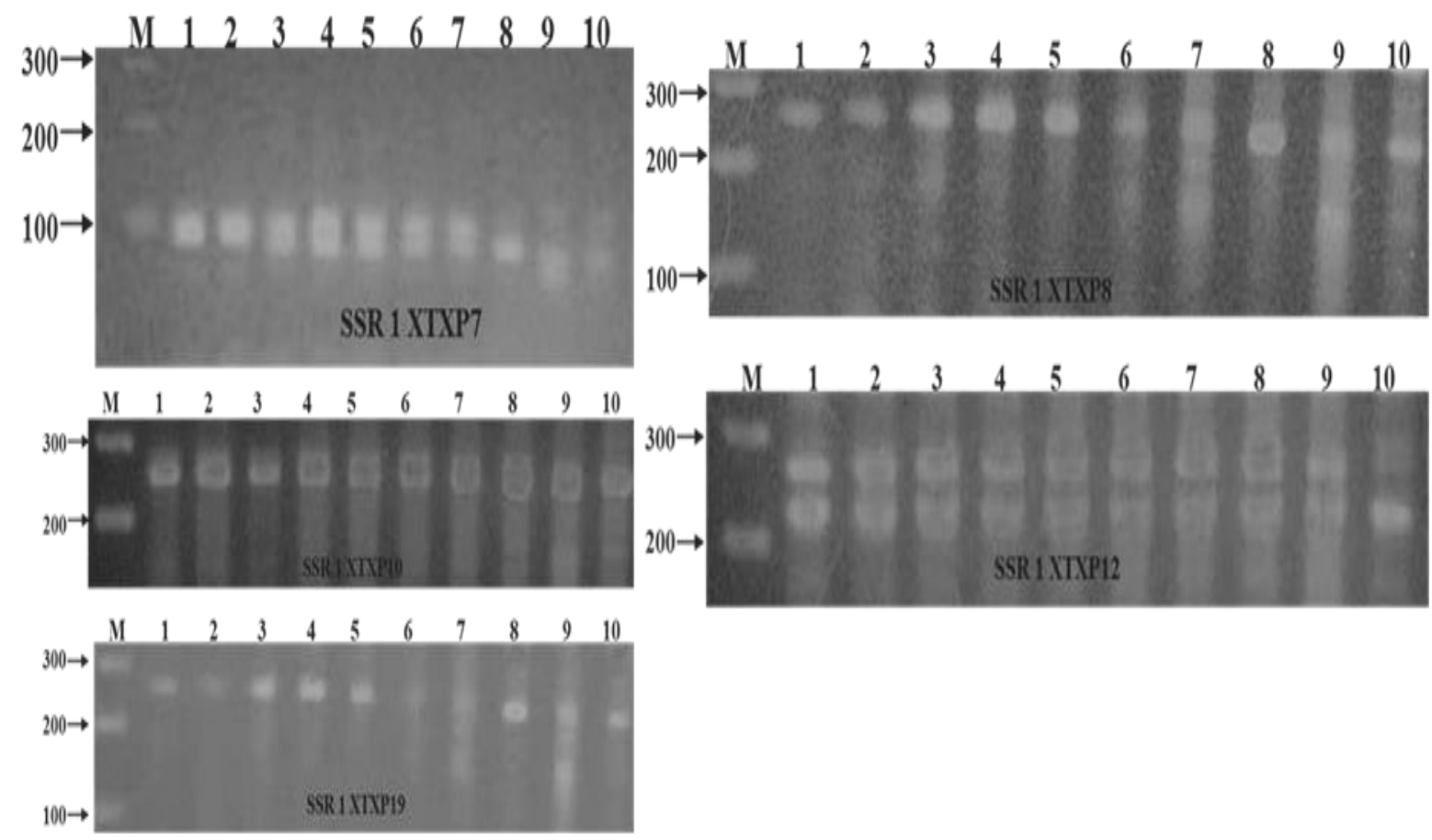

Fig. 3. DNA polymorphism of the Egyptian and Yemen wheat cultivars using SSR markers (1) Sakha93, (2) Geiza168, (3) Gammeiza9, (4) Shakha94, (5) misr1, (6) Gammeiza10, (7) Gammeiza11, (8) Sids 1, (9) Sids 2, and (10) Sakha 95.

\section{REFERENCES}

Ashraf, M., T. McNeilly and A.D. Bradshaw. 1986. The response of selected salt tolerant and normal lines of four grass species to $\mathrm{NaCl}$ in sand culture. New phytologist 104 : 453-461.

Ball, M.C. 1988. Salinity tolerance in the mangroves, Aegceras corniculatum and Avicennia marina. I. Water use in relation to growth, carbon partitioning and salt tolerance. Australian J. of Plant Physiology. 15:447-464.

Bates, L.S., R.P. Waldren and L.D. Tear. 1973. Rapid determination of free proline for water-stress studies. Plant Soil. 39: 205-207.

Chao, S.M., W.J. Zhang, J. Dubcovsky and M. Sorrells. 2007. Evaluation of genetic diversity and genome-wide linkage disequilibrium among US wheat (Triticum aestivum L.) germplasm representing different market classes. Crop Sci. 47:1018-1030.

Collard, B.C.Y, M.Z.Z. Jahufer, J.B. Brouwer and E.C.K. Pang. 2005. An introduction to markers, quantitative trait loci (QTL) mapping and marker-assisted selection for crop improvement: The basic concepts. Euphytica. 142: 169196.

Hamada, A.A. 1996. Genetical analyses of diallel cross in bread wheat under different environmental conditions in Egypt. Indian J. of Genetics and Plant Breeding, 56: 34-48.

Hasegawa, P.M., R.A. Bressan, J.K. Zhu and H.J. Bohnert. 2000. Plant cellular and molecular responses to high salinity. Annual Review of Plant Physiology and Plant Molecular Biology. 51:463-499.
Hassanein, A. 1999. Alternation in protein and esterase wheat in response to salinity stress. Biologia plantarum: $42(2)$ : 241248.

Hu, Y., U. Schmidhalter. 1998. Spatial distributions and net deposition rates of mineral elements in the elongating wheat (Triticum aestivum L.) leaf under saline soil conditions. Planta. 204: 212-219.

Iqbal, N., M.Y. Ashraf, J. Farrukh, M. Vicente and A. Kafeel. 2006. Nitrate reduction and nutrient accumulation in wheat (Triticum aestivum L.) grown in soil salinization with four different salts. J. Plant Nutrition. 29: 409-421.

Joly, R.J., A. Maggio and M.P. Reddy. 2000. Leaf gas exchange and solute accumulation in the halophyte Salvadora persica grown at moderate salinity. Environmental and Experimental Botany: 44. 31-38.

Jones, N., H. Ougham and H. Thomas. 1997. Markers and mapping: We are all geneticists now. New phytologist. 137: 165-177.

Khan, D.K., M. Tuna, M. Tal, A. Nejidat and A. GolanGoldhirsh. 2009. Variability in the pattern of random amplied polymorphic DNA.Electrophoresis. 18:2852-2856.

Kong, I., J.Dong and G.E. Hart. 2000. Characterization, linkage map positions, and allelic differentiation of (Sorghum bicolour (L.) Moench) by DNA simple-sequence repeats (SSRs). Theoretical and Applied Genetics. 101:438-448.

Munns, R., James, R.A. 2003. Screening methods for salinity tolerance: a case study with tetraploid wheat. Plant Soil. 59: $1-18$. 
Nawaz,R., P . Thompson, J. McNaught and S. Ananiadou. 2010. Meta Knowledge Annotation of Bio Events. In Proceedings of LREC. 2498 - 2507.

Rafalski, J.A. and S.V. Tingey. 1993. Genetic diagnostics in plant breeding: RAPDs, microsatellites, and machines. Trends in Genetics. 9:275-280.

Sabrah, N.S. 1980. Genetical and cytological studies on maize. Ph.D. Thesis, Faculty of Agriculture, University of Alexandria , Egypt.
Shitsukawa, N., A. Takagishi, C. Ikari, S. Takumi and K. Murai. 2006. WFL, a wheat FLORICAULA/LEAFY ortholog, is associated with spikelet formation as lateral branch of the inflorescence meristem. Genes Genetic System. 81:3-20.

Siugh, P.K. 1994. Genetic diversity in durum wheat germplasm Annals of Agricultural Research. 15: 418 - 422.

Williames, J.K., A. Kubelik, K.J .Livak, J.A. Rafalski and S.V. Tingey. 1990. DNA polymorphisms amplified by arbitrary primers are useful as genetic markers. Nucleic Acids Research. 18:6531-6535.

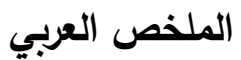

\section{دراسات جزيئية ووراثية خلوية على القدرة لتحمل الاجهاد البيئح فى القمح \\ محمد حسن حربى}

طول الساق وطول الجذر وعدد الاوراق وعدد الاوراق لكل

نبات وعدد الجذور لكل نبات كما تم قياس الحمض الاميني

$$
\text { • برولين }
$$

• وتم توظيف معلمات جزيئية وكيموحيوية وسيتولوجية وذلك

$$
\text { تحت ظروف اجهاد بسبب الملوحة . }
$$

وأظهرت نتائج البحث الحالي ان هناك فروقاً جوهرية عالية لتحمل بعض الأصناف للملوحة وذلك باستخدام تكنيك

$$
\text { تحليل تفاعل البلمرة المتسلسل السريع • }
$$

هذا وقد اظهرت النتائج تحديد هVحزة منها به حزمة متعددة الثكل المظهري كما أظهر تكنيك ISSR ان هناك انك

$$
\text { | } 1 \text { حزمة منها ^ حزم متعددة الثكل المظهرى . }
$$

أهمية هذا البحث لمربى القمح انه يستطيع في برامج التربية والانتخاب ان يحصل على تراكيب وراثية جديدة ومميزة ومفيدة في تربية القهح لتحمل الملوحة حيث ان القهح يعتبر من المحاصير الهامة والاستراتيجية على مستوى العالم.

$$
\begin{aligned}
& \text { يهدف البحث الحالي لدراسة الاجهاد البيئى متمثلاً في القدرة } \\
& \text { على تحمل الملوحة لأصناف من القـح. } \\
& \text { ولتحقيق هذا الغرض تم إجراء دراسات جزئية وكيموحيوية } \\
& \text { ووراثية خلوية . } \\
& \text { تم اجراء هذا البحث باستخدام • } 1 \text { أصناف من القـح وهى :- } \\
& \text { 1. }
\end{aligned}
$$

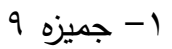

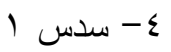

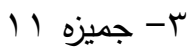

$$
\begin{aligned}
& \text { 1- مصر 1 n }
\end{aligned}
$$

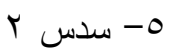

$$
\begin{aligned}
& \text { 1 } 14
\end{aligned}
$$

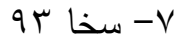

$$
\begin{aligned}
& 90 \text { (- } 90
\end{aligned}
$$

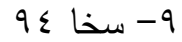

$$
\begin{aligned}
& \text { هذا وقد تم زراعة عشرة حبوب من كل صنف فى اسس } \\
& \text { وذلك بعد غسلها بماء مقضر وقد تم معاملة الحبوب بكلوريد } \\
& \text { الصوديون بعد ثمانية ايام من الانبات وذلك تحت اربعة } \\
& \text { مستويات مختلفة وهى ( صفر ، ، } 0 \text { ، . 10 ، . . ب ) وتم } \\
& \text { قياس الخواص المورفولوجية فى المجموع الخضرى مثل }
\end{aligned}
$$

